\title{
Genomic Heterogeneity of Strains Nodulating Chickpeas (Cicer arietinum L.) and Description of Rhizobium mediterraneum sp. nov. SARAH M. NOUR, ${ }^{1,2 *}$ JEAN-CLAUDE CLEYET-MAREL, ${ }^{2}$ PHILIPPE NORMAND, ${ }^{\prime}$ AND MARIA P. FERNANDEZ ${ }^{1}$
}

Centre National de la Recherche Scientifique, Unité de Recherche Associée 1977 "Ecologie Microbienne du Sol," Université Lyon I, 69622 Villeurbanne Cedex, ${ }^{1}$ and Institut National de la Recherche Agronomique, Laboratoire de Recherche sur les Symbiotes des Racines, 34060 Montpellier, ${ }^{2}$ France

\begin{abstract}
The genetic diversity of chickpea strains was studied by using 30 isolates obtained from nodules on chickpeas growing in uninoculated fields over a wide geographic range. The following taxonomic approaches were used: DNA-DNA relatedness analysis, restriction fragment length polymorphism analysis of the amplified 16S ribosomal DNA (rDNA) intergenic spacer (IGS), and total 16S rRNA sequence analysis. The division of chickpea-infective strains into two major phylogenetic groups (groups $A$ and B) that has been described previously was confirmed by the polymorphism of the 16S IGS rDNA. We identified a total of five genomic species, including the previously described species Rhizobium ciceri. All of the group B strains except one were homogeneous and belonged to a single genomic species corresponding to $R$. ciceri. Group A was heterogeneous, containing three genomic species and five strains that remained unclassified, and its members had very different PCR restriction fragment length polymorphism profiles. The complete 16S rRNA sequences of strains representing the two major groups, $R$. ciceri UPM-Ca7 ${ }^{\mathrm{T}}$ ( $\mathrm{T}=$ type strain) and genomic species 2 strain UPM-Ca36 ${ }^{\mathrm{T}}$, exhibited 19 mismatches. Both of these strains belonged to the Rhizobium loti-Rhizobium huakuii branch; $R$. ciceri UPM-Ca $7^{\mathrm{T}}$ was closely related to $R$. loti, and strain UPM-Ca36 ${ }^{\mathrm{T}}$ was clearly separated from $R$. ciceri and closely related to $R$. huakuii. Thus, genomic species 2 could be distinguished from $R$. ciceri by its 16S rRNA sequence, by DNA relatedness data, by the polymorphism of the 16S IGS rDNAs, and by previously described multilocus enzyme electrophoresis results and phenotypic characteristics. Therefore, we propose that strains belonging to genomic species 2 should be classified in a new species, Rhizobium mediterraneum, and that strain UPM-Ca36 should be the type strain.
\end{abstract}

Numerous studies to clarify the taxonomy and phylogeny of bacteria that are able to induce nodules on leguminous plants are now being carried out. Rapid changes in the classification of these organisms are occurring, and new genera and especially new species are being described. In 1984 in Bergey's Manual of Systematic Bacteriology (15) the following species in the genus Rhizobium were recognized: Rhizobium leguminosarum, Rhizobium meliloti, and Rhizobium loti. Since then, isolates obtained from new or partially studied host plants have led to the delineation of six new species, Rhizobium galegae (18), Rhizobium fredii (29), Rhizobium huakuii (4), Rhizobium etli (30), Rhizobium tropici (20), and Rhizobium ciceri (25). Recently, De Lajudie et al. (7) studied isolates obtained from different Acacia and Sesbania host plants and found that on the basis of $16 \mathrm{~S}$ rRNA sequences most of the strains clustered on the $R$. meliloti- $R$. fredii branch. On the basis of polyphasic results, these authors described a distinct genus for this group, the genus Sinorhizobium. The genus Sinorhizobium includes Sinorhizobium meliloti and Sinorhizobium fredii (previously $R$. meliloti and $R$. fredii, respectively), as well as two new species, Sinorhizobium teranga and Sinorhizobium saheli.

Bacteria that are able to establish an effective nitrogen-fixing symbiosis with chickpeas have been studied intermittently, and no strains or only a few strains have been included in previous taxonomic studies of the family Rhizobiaceae, which has led to

${ }^{*}$ Corresponding author. Mailing address: U.R.A. C.N.R.S. 1977 "Ecologie Microbienne du Sol," Université Lyon I, Bat. 741, 43 bd. du 11 Novembre 1918, 69622 Villeurbanne Cedex, France. Phone: (33) 72 4482 00. Fax: (33) 72431223. contradictory conclusions. On the one hand, several authors concluded that the chickpea rhizobia form a unique group on the basis of the specificity of the host plant-rhizobium relationship (10), serological and antigenic characteristics $(6,17)$, cultural traits, and the polymorphism of the nifHD genes (3). On the other hand, Jarvis et al. (14) proposed that the chickpea strains should be classified as R. loti or Bradyrhizobium sp. (Cicer arietinum L.) strains, depending on their generation times, and this view prevailed until recently. These contradictory conclusions led us to reexamine the diversity of the chickpea rhizobia, and we used the following genomic and phenotypic approaches to do this: multilocus enzyme electrophoresis, an analysis of the polymorphism of the $16 \mathrm{~S}$ intergenic spacer (IGS) ribosomal DNA (rDNA), an analysis of auxanographic and cultural characteristics, a 16S rRNA sequence analysis, and a DNA relatedness analysis $(24,25)$. Our conclusions were as follows: (i) all of the chickpea Rhizobium strains belong to the genus Rhizobium regardless of generation time; (ii) these organisms constitute a separate branch that is closely related to but can be clearly differentiated from $R$. loti; (iii) two phylogenetic lineages (groups $\mathrm{A}$ and $\mathrm{B}$ ) are present; and (iv) the homogeneous group $B$ strains belong to the recently described species $R$. ciceri (25). Groups A and B appeared to be genetically divergent, and preliminary DNA-DNA relatedness results obtained with two strains belonging to each group suggested that the group A strains do not belong to the species $R$. ciceri (25).

In order to examine the genetic diversity of chickpea strains at the species level, we determined DNA-DNA relatedness values since DNA-DNA relatedness is the major criterion used to delineate genospecies $(11,33)$. We also examined ribosomal 
TABLE 1. Bacterial strains examined

\begin{tabular}{|c|c|c|c|}
\hline Strain $^{a}$ & $\begin{array}{l}\text { RFLP } \\
\text { group }\end{array}$ & $\begin{array}{c}\text { Geographic } \\
\text { origin }\end{array}$ & Reference(s) \\
\hline \multicolumn{4}{|l|}{$R$. ciceri strains } \\
\hline UPM-Ca $7^{\mathrm{T}^{\mathrm{C}}}\left(=\mathrm{ATCC} 51585^{\mathrm{T}}\right)$ & $\mathrm{B}^{c}$ & Spain & $3,24,25$ \\
\hline $3 \mathrm{HOa} 10$ & $\mathrm{~B}^{\mathrm{c}}$ & United States & $3,24,25$ \\
\hline IC-2091 (= LMG15046) & $\mathrm{B}^{c}$ & India & $3,24,25$ \\
\hline UPM-Ca116 & $\mathbf{B}^{c}$ & Spain & $3,24,25$ \\
\hline 522 & $\mathrm{~B}^{c}$ & Russia & $3,24,25$ \\
\hline IC-2018 & $\mathrm{B}^{c}$ & Turkey & $3,24,25$ \\
\hline CP-76 & $\mathrm{B}^{d}$ & Morocco & This study \\
\hline CP-77 & $\mathrm{B}^{d}$ & Morocco & This study \\
\hline $\mathrm{CP}-92$ & $\mathrm{~B}^{d}$ & Syria & This study \\
\hline \multicolumn{4}{|l|}{$\begin{array}{l}\text { Rhizobium sp. (C. arietinum L.) } \\
\text { strains }\end{array}$} \\
\hline $3 \mathrm{HOa} 9$ & $\mathrm{~B}^{c}$ & United States & $3,24,25$ \\
\hline $\mathrm{Ca}-7$ & $\mathrm{~A}^{c}$ & India & $3,24,25$ \\
\hline IC-72M (= ATCC 51586) & $\mathrm{A}^{c}$ & India & $3,24,25$ \\
\hline IC -60 & $A^{c}$ & India & $3,24,25$ \\
\hline $\mathrm{H}-45$ & $A^{c}$ & India & $3,24,25$ \\
\hline IC -6 & $A^{c}$ & India & $3,24,25$ \\
\hline UPM-Ca 142 & $\mathrm{~A}^{c}$ & Spain & $3,24,25$ \\
\hline UPM-Ca36 ${ }^{\mathrm{T}}$ & $\mathrm{A}^{c}$ & Spain & $3,24,25$ \\
\hline $\mathrm{CP}-8$ & $\mathrm{~A}^{d}$ & Syria & This study \\
\hline $\mathrm{CP}-12$ & $\mathrm{~A}^{d}$ & India & This study \\
\hline $\mathrm{CP}-14$ & $\mathrm{~A}^{d}$ & India & This study \\
\hline CP-18 & $\mathrm{A}^{d}$ & Lebanon & This study \\
\hline CP-19 & $\mathrm{A}^{d}$ & Syria & This study \\
\hline CP-24 & $\mathrm{A}^{d}$ & Syria & This study \\
\hline CP-28 & $\mathrm{A}^{d}$ & Tunisia & This study \\
\hline CP-47 & $\mathrm{A}^{d}$ & Morocco & This study \\
\hline CP-54 & $\mathrm{A}^{d}$ & Morocco & This study \\
\hline CP-78 & $\mathrm{A}^{d}$ & Italy & This study \\
\hline USAB67 & $\mathrm{C}^{c}$ & India & $3,24,25$ \\
\hline CP-9 & $\mathrm{C}^{d}$ & Jordan & This study \\
\hline CP-91 & $\mathrm{C}^{d}$ & Nepal & This study \\
\hline
\end{tabular}

a ATCC, American Type Culture Collection, Rockville, Md.; LMG, Collection of Bacteria of the Laboratorium voor Microbiologic, University of Ghent, Ghent, Belgium. Strains whose designations begin with CP were obtained from D. Beck, International Center for Agricultural Research in Dry Areas, Aleppo, Syria. "RFLP groups obtained by amplification and digestion of 16S IGS rDNA.

Data from references 24 and 25.

${ }^{d}$ Data from this study.

gene polymorphism, which classically has allowed workers to clarify phylogenetic relationships between species. The method which we used was a PCR restriction fragment length polymorphism (RFLP) analysis of the 16S IGS rDNA since this method allowed us to rapidly position a large number of strains phylogenetically and used the more divergent IGS, which increased the discriminative power of the analysis. Furthermore, the inability of partial 16S rRNA sequences to distinguish groups $\mathrm{A}$ and $\mathrm{B}$, which were highly divergent as determined by polyphasic approaches (25), led us to determine whether these taxa belong to a unique phylum by using total $16 \mathrm{~S}$ rRNA sequencing. In this study, we analyzed 30 chickpea strains, including 15 collection strains used in our previous studies $(24$, 25 ) and 15 isolates obtained from root nodules on chickpeas growing in uninoculated fields in diverse geographic regions in the Middle East and Far East.

\section{MATERIALS AND METHODS}

Strains and culture. The origins of the 30 strains which we studied are shown in Table 1. All of the strains whose designations begin with $\mathrm{CP}$ were obtained from the International Center for Agricultural Research in Dry Areas, Aleppo, Syria. These strains were isolated from root nodules on chickpeas growing in areas with no history of rhizobium inoculation. The other strains which we used are collection strains obtained from T. Ruiz-Argueso, Universidad Politécnica,
Madrid, Spain. The bacteria were maintained on yeast extract-mannitol agar slants (32) at $4^{\circ} \mathrm{C}$, and repeated streaking was performed to check for purity. Cells were grown at $28^{\circ} \mathrm{C}$ in yeast extract-mannitol medium; however, in order to limit exopolysaccharide formation, maltose was used instead of mannitol.

DNA extraction. Previously described methods were used to extract (2) and purify (25) DNA

DNA-DNA hybridization and thermal stability of duplexes. Native DNAs from R. ciceri UPM-Ca7 ${ }^{\mathrm{T}}(\mathrm{T}=$ type strain $)$, IC-2018, 3HOa9, Ca-7, IC-60), and CP-18 were labelled by nick translation (26) by using tritium-labelled nucleotides (Amersham International, Amersham, England). Levels of DNA relatedness were determined by using the S1 nuclease-trichloroacetic acid method (12) at the optimal temperature for DNA reassociation $\left(70^{\circ} \mathrm{C}\right)$.

The thermal stability of each reassociated DNA was estimated by determining its denaturation temperature (the temperature at which $50 \%$ of the doublestranded DNA became denatured and hydrolyzable by SI nuclease) as described previously (5), with slight modifications (9). The temperature of the mixture was increased from 70 to $95^{\circ} \mathrm{C}$ in $5^{\circ} \mathrm{C}$ increments. The levels of divergence between hybrid DNAs were inversely proportional to the thermal stabilities of the hybrids: this was expressed by calculating the $\Delta T_{m}$, which was the difference between the denaturation temperatures of the heterologous and homologous duplexes.

Amplification and restriction enzyme analysis of 16S IGS rDNA. The oligonucleotides used as primers for amplification of the 16S IGS rDNA region by the PCR were 5'-GGAGAGTTAGATCTTGGCTCAG-3' (primer FGPS6-63; 5 end of the 16S rRNA gene) and 5'-CCGGGTTTCCCCATTCGG-3' (primer FGPL132'-38; 5' end of the 23S rRNA gene) (23). Amplification reactions were carried out by using the protocol of Mullis and Faloona (21), with some modifications. PCR were performed in a final volume of $50 \mu \mathrm{l}$ under a thin surface layer of paraffin oil to prevent evaporation. Each reaction mixture contained approximately $0.5 \mu \mathrm{g}$ of genomic DNA, buffer $(10 \mathrm{mM}$ Tris $\mathrm{HCl}|\mathrm{pH} 8.2|, 1.5$ $\mathrm{mM} \mathrm{MgCl}, 50 \mathrm{mM} \mathrm{KCl}, 0.01 \%$ [wt/vol] gelatin), $20 \mu \mathrm{M}$ dATP, $20 \mu \mathrm{M}$ dTTP, 20 $\mu \mathrm{M}$ dGTP, $20 \mu \mathrm{M}$ dCTP, each primer at a concentration of $0.1 \mu \mathrm{M}$, and $2.5 \mathrm{U}$ of TaqI DNA polymerase (Gibco-Bio-Rad Laboratories, Cergy-Pontoise, France). Amplification reactions were carried out with a dry-block thermal cycler (Biometra Trio thermoblock) by using the following program: initial denaturation for $3 \mathrm{~min}$ at $95^{\circ} \mathrm{C}, 35$ cycles consisting of denaturation for $1 \mathrm{~min}$ at $95^{\circ} \mathrm{C}$ annealing for $1 \mathrm{~min}$ at $55^{\circ} \mathrm{C}$, and extension for $2 \mathrm{~min}$ at $72^{\circ} \mathrm{C}$, and final extension for $3 \mathrm{~min}$ at $72^{\circ} \mathrm{C}$. To analyze the amplification products, $5-\mu l$ aliquots were electrophoresed on horizontal $0.8 \%$ (wt/vol) agarose gels in TBE buffer $(89 \mathrm{mM}$ Tris borate. $89 \mathrm{mM}$ boric acid, $2 \mathrm{mM}$ EDTA; $\mathrm{pH} 8$ ) at $4 \mathrm{~V} / \mathrm{cm}$ for $1 \mathrm{~h}$. The gels were stained in an aqueous solution containing $0.4 \mathrm{mg}$ of ethidium bromide per liter and were photographed under UV light $(302 \mathrm{~nm})$ by using Ilford type HP5 film. The sizes of amplified fragments were estimated by comparing them with a $1-\mathrm{kb}$ ladder that was used as a molecular weight standard (Gibco-Bio-Rad Laboratorics). The size of the IGS was then calculated by subtracting the size of the $16 \mathrm{~S}$ rDNAs of members of the Rhizobiaceae (34) (approximately $1,500 \mathrm{bp}$ ) from the size of the $16 \mathrm{~S}$ IGS rDNA amplified region.

Restriction enzyme digestions of PCR products were performed in 20)- $\mu$ l (total volume) mixtures containing $7 \mu \mathrm{l}$ of amplified DNA and 10 to $12 \mathrm{U}$ of the following restriction endonucleases: $A l u I$ I, CfoI, $M s p I, N d e I I$, and $S a u 96.1$ (all obtained from Boehringer Mannheim, Meylan, France) and HaelII and Rsal (both obtained from Gibco-Bio-Rad Laboratories). The reaction conditions used were those recommended by the manufacturers. The restricted fragments were separated by horizontal gel electrophoresis in TBE buffer by using a $3 \%$ (wt/vol) Nusieve (FMC, Rockland, Maine) agarose gel containing $1 \mu \mathrm{g}$ of ethidium bromide per $\mathrm{ml}$. The molecular weight standards used were 123-bp and 1 -kb ladders (Gibco-Bio-Rad Laboratories). The gels were electrophoresed at $2.3 \mathrm{~V} / \mathrm{cm}$ for $3 \mathrm{~h}$.

The size of each restricted fragment was calculated, and the profiles of the strains were compared. Bands of fragments shorter than 90 bp were not taken into consideration, since they were not resolved reproducibly. Thus, the sizes of the PCR products estimated by adding the sizes of the restriction fragments were slightly smaller than the sizes estimated for the undigested fragments. The genetic relationship between two amplified DNAs was evaluated by using the similarity coefficient $F$, which was calculated as follows: $F=2 n_{x y} / n_{\mathrm{x}}+n_{y}$, where $n_{x y}$ was the number of comigrating fragments (considering all enzymes) and $n_{x}$ and $n_{y}$ were the total numbers of bands for strains $x$ and $y$, respectively. The genetic distance for each pair of strains was determined by calculating the $D$ value as described by Nei and $\mathrm{Li}$ (22), and a dendrogram was constructed by using the unweighted pair group with arithmetic average algorithm of Sneath and Sokal (31).

Nucleotide sequences of $16 \mathrm{~S}$ rRNA genes and data analysis. The 16S rRNA genes were amplified by using the PCR conditions described above and primers FGPS5-255 (5'-TGGAAAGCTTGATCCTGGCT-3') and FGPS1509'-153 (5'-A AGGAGGGGATCCAGCCGCA-3'), which contain restriction sites for HindIII and $B a m H I$ (the underlined portions), respectively (1). The amplified products were purified with a Gencelean kit (Bio 101, La Jolla, Calif.) and were transformed into Escherichia coli DH5 $\alpha \mathrm{F}^{\prime}$ (Bethesda Research Laboratories) as described by Maniatis et al. (19). Plasmid purification from strain $\mathrm{DH} 5 \alpha \mathrm{F}^{\prime}$ was performed by alkaline lysis in which a QIAGEN Midi-prep kit (Diagen, Düsseldorf, Germany) was used. Seven primers (primers FGPS310-20) [5'-GAGACAC GGCCCAGACTCCT-3'], FGPS485-292 [5'-CAGCAGCCGCGGTAA-3'], FGPS747-293 [5'-AACAGGATTAGATAC-3'], FGPS1047-295 [5'-ATGTTGG 
TABLE 2. Levels of DNA relatedness for 30 chickpea strains

\begin{tabular}{|c|c|c|c|c|c|c|c|}
\hline \multirow{2}{*}{ Source of unlabelled DNA } & \multirow{2}{*}{ RFLP group ${ }^{a}$} & \multicolumn{6}{|c|}{$\%$ Relatedness to ${ }^{3} \mathrm{H}$-labelled DNA from: } \\
\hline & & $\mathrm{UPM}-\mathrm{Ca} 7^{\mathrm{T}}$ & IC-2018 & 3HOa9 & CP-18 & $\mathrm{Ca}-7$ & IC- 60 \\
\hline \multicolumn{8}{|l|}{$R$. ciceri strains } \\
\hline UPM-Ca $7^{\mathrm{T}}$ & $\mathrm{B}$ & $100^{b}$ & $\mathrm{ND}^{c}$ & ND & ND & ND & 26 \\
\hline 3HOa10 & B & 78 & ND & 37 & ND & 41 & 31 \\
\hline IC-2091 & $\mathrm{B}$ & 83 & 72 & 35 & 40 & 30 & 29 \\
\hline UPM-Ca116 & B & 68 & ND & 38 & 34 & 31 & 31 \\
\hline 522 & $\mathrm{~B}$ & 75 & 71 & 35 & 30 & $32(12.0)^{d}$ & 30 \\
\hline IC-2018 & B & ND & 100 & 28 & 28 & 20 & 27 \\
\hline CP-77 & B & 65 & 89 & 32 & 28 & 28 & 30 \\
\hline CP-76 & B & ND & 70 & 36 & 31 & ND & ND \\
\hline CP-92 & B & ND & 102 & 30 & 29 & 23 & 27 \\
\hline Genomic species 1 strain $3 \mathrm{HOa} 9$ & B & 53 & 42 & 100 & 31 & 27 & 29 \\
\hline \multicolumn{8}{|l|}{ Genomic species 2 strains } \\
\hline UPM-Ca142 & A & 48 & 38 & 31 & 81 & $53(6.0)$ & 43 \\
\hline UPM-Ca36 ${ }^{\mathrm{T}}$ & A & 42 & 40 & 28 & 82 & $50(6.5)$ & 43 \\
\hline $\mathrm{CP}-18$ & A & ND & 41 & 30 & 100 & $56(6.5)$ & 37 \\
\hline CP-12 & A & ND & 39 & 24 & 99 & 49 & 32 \\
\hline CP-24 & A & 35 & 32 & 24 & 100 & 48 & 35 \\
\hline CP-8 & A & ND & 32 & 23 & 99 & 52 & 36 \\
\hline CP-28 & A & ND & 34 & 21 & 100 & 45 & 34 \\
\hline \multicolumn{8}{|l|}{ Genomic species 3 strains } \\
\hline $\mathrm{Ca}-7$ & A & 36 & 32 & 26 & $63(6.0)$ & 100 & ND \\
\hline IC-72M & A & 34 & ND & ND & ND & 104 & ND \\
\hline CP-14 & A & ND & 36 & 24 & $54(6.5)$ & 91 & 40 \\
\hline \multicolumn{8}{|l|}{ Genomic species 4 strains } \\
\hline IC-60 & A & 36 & 30 & 24 & $46(10.5)$ & 37 & 100 \\
\hline H-45 & A & 38 & ND & ND & ND & 44 & 77 \\
\hline \multicolumn{8}{|l|}{ Unclassified strains } \\
\hline IC-6 & A & 29 & 34 & 27 & $63(6.5)$ & $56(5.5)$ & 37 \\
\hline CP-47 & A & ND & 35 & 29 & 56 & ND & 38 \\
\hline CP-54 & A & ND & 34 & 17 & $55(8.0)$ & 53 & 36 \\
\hline CP-19 & A & ND & 37 & 24 & ND & 47 & 35 \\
\hline CP-78 & A & ND & 34 & 24 & 48 & 49 & 33 \\
\hline USAB67 & $\mathrm{C}$ & 29 & 27 & 23 & 33 & 23 & 36 \\
\hline CP-91 & $\mathrm{C}$ & ND & 23 & 20 & 20 & 19 & 17 \\
\hline CP-9 & $\mathrm{C}$ & ND & 33 & 22 & 29 & 25 & 26 \\
\hline
\end{tabular}

a Groups determined by analyzing RFLP of the amplified and digested 16S IGS rDNA region (24, 25; this study).

${ }^{b}$ Level of DNA relatedness at $70^{\circ} \mathrm{C}$.

c ND, not determined.

${ }^{d}$ The numbers in parentheses are $\Delta T_{m}$ values (in degrees Celsius).

GTTAAGTC-3'], FGPS1176'-112 [5'-GGGGCATGATCACTTGACGTC-3'], FGPS910'-270 [5'-AGCCTTGCGGCCGTACTCCC-3'], and FGPS505'-313 [5'GTATTACCGCGGCTGCTG-3']), as well as primers T3 and T7, which were supplied by Pharmacia LKB, Uppsala, Sweden, were necessary to sequence both strands of the $16 \mathrm{~S}$ rRNA molecule. The sequencing procedure was performed by using T7 sequencing kits (Pharmacia LKB) and was based on the dideoxy chain termination method described by Sanger et al. (28).

Sequences were aligned and compared by using the Clustal program (13). Matrix pairwise comparisons were corrected for multiple base substitutions by the method of Kimura (16), and a phylogenetic tree was constructed by the neighbor-joining method (27). Gap-containing positions were omitted from the computations. A bootstrap confidence analysis was performed by using 1,000 replications to determine the reliability of the tree topology obtained (8).

Nucleotide sequence accession numbers. The 16S rRNA gene sequences of strains UPM-Ca $7^{\mathrm{T}}$ and UPM-Ca $36^{\mathrm{T}}$ have been deposited in the GenBank data library under accession numbers U07934 and L38825, respectively. The accession numbers of the nucleotide sequences of the $16 \mathrm{~S}$ rRNAs of the organisms belonging to the Rhizobiaceae and other related bacteria used for comparison are as follows: $R$. loti group B strain LMG4284, X67230; $R$. loti group A strain LMG6125 , X67229; isolate ORS1001, obtained from Acacia senegal, X68389; $R$. huakuii, D12797; Phyllobacterium myrsinacearum, D12789; S. meliloti LMG6133, X67222; $S$. fredii LMG6217, X67231; $R$. galegae LMG6214, X67226; Agrobacterium tumefaciens LMG196, X67223; $R$. tropici IFO15247, D11344; $R$. leguminosarum group A strain LMG9518, X67233; . tropici group IIB strain LMG9517, X67234; Rhizobium sp. strain LMG9509, X67232; Agrobacterium rhizogenes LMG152, X67224; Bradyrhizobium japonicum, X66024; and Azorhizobium caulinodans LMG6465, X67221.

\section{RESULTS}

DNA-DNA hybridization experiments. The levels of DNA relatedness of 30 strains and the $\Delta T_{m}$ values of 10 strains with six reference strains are shown in Table 2. Labelled DNAs from $R$. ciceri UPM-Ca $7^{\mathrm{T}}$ and IC-2018 exhibited DNA relatedness values of 65 to $100 \%$ with seven other group B strains, and together these strains constituted a tight genomic group which corresponded to $R$. ciceri since it contained the type strain of the species (strain UPM-Ca7). Strain 3HOa9 is the only group B strain which did not belong to $R$. ciceri; this strain exhibited $53 \%$ relatedness with the type strain of $R$. ciceri and less than $38 \%$ relatedness with eight other $R$. ciceri strains. Twelve group A strains fell into three genomic species. Genomic species 2 contained seven strains which exhibited 81 to $100 \%$ DNA relatedness with strain CP-18 and 46 to $63 \%$ DNA relatedness $\left(\Delta T_{m}, 6.0\right.$ to $\left.10.5^{\circ} \mathrm{C}\right)$ with the other group A strains. This genomic species exhibited less than $40 \%$ DNA relatedness with group $\mathrm{B}$ and $\mathrm{C}$ strains. Genomic species 3 comprised three strains that exhibited more than $91 \%$ DNA relatedness with strain $\mathrm{Ca}-7$ and 37 to $56 \%$ DNA relatedness $\left(\Delta T_{m},>6.0^{\circ} \mathrm{C}\right)$ with the other group A strains. These organisms exhibited low levels of DNA relatedness (20 to $41 \%$ ) with 
TABLE 3. 16S IGS rDNA restriction patterns of 24 chickpea strains

\begin{tabular}{|c|c|c|c|c|c|c|c|c|}
\hline \multirow{2}{*}{ Strain } & \multicolumn{7}{|c|}{ Restriction enzyme pattern ${ }^{a}$} & \multirow{2}{*}{$\underset{\text { type }}{16 S \text { IGS rDNA }}$} \\
\hline & RsaI & $A l u \mathrm{I}$ & CfoI & HaeIII & MspI & NdeII & Sau 96.1 & \\
\hline \multicolumn{9}{|l|}{ Group A strains } \\
\hline CP-18 & $\mathrm{R} 1$ & A1 & $\mathrm{C} 1$ & H1 & M1 & N1 & S1 & I \\
\hline CP-12 & $\mathrm{R} 1$ & A1 & $\mathrm{C} 1$ & H1 & M1 & N1 & S1 & I \\
\hline CP-24 & $\mathrm{R} 1$ & A1 & $\mathrm{C} 1$ & $\mathrm{Hi}$ & M1 & N1 & S1 & I \\
\hline CP- 8 & $\mathrm{R} 1$ & A1 & $\mathrm{Cl}$ & H1 & M1 & N1 & S1 & I \\
\hline CP-28 & $\mathrm{R} 1$ & A1 & $\mathrm{Cl}$ & H1 & M1 & N1 & S1 & I \\
\hline $\mathrm{H}-45$ & $\mathrm{R} 2$ & A2 & $\mathrm{C} 2$ & $\mathrm{H} 2$ & M2 & N2 & S2 & II \\
\hline UPM-Ca142 & $\mathrm{R} 3$ & A3 & $\mathrm{C} 3$ & $\mathrm{H} 3$ & M3 & N3 & S3 & III \\
\hline CP-54 & R4 & A4 & $\mathrm{C} 4$ & $\mathrm{H} 4$ & M4 & N4 & $\mathrm{S} 4$ & IV \\
\hline IC -6 & R4 & A5 & C5 & H5 & M5 & N5 & S5 & $\mathrm{V}$ \\
\hline CP-19 & $\mathrm{R} 1$ & A6 & C6 & H6 & M6 & N6 & S6 & VI \\
\hline IC-72M & R5 & A7 & $\mathrm{C} 7$ & $\mathrm{H} 7$ & M7 & N7 & S7 & VII \\
\hline $\mathrm{Ca}-7$ & R5 & A7 & C7 & $\mathrm{H} 7$ & M7 & N7 & S7 & VII \\
\hline CP-14 & R5 & A7 & C7 & $\mathrm{H} 7$ & M7 & $\mathrm{N} 7$ & S7 & VII \\
\hline CP-47 & $\mathrm{R} 1$ & A8 & $\mathrm{C} 1$ & H8 & M4 & N8 & S8 & VIII \\
\hline CP-78 & R6 & A9 & $\mathrm{C} 8$ & H9 & M8 & N9 & S9 & IX \\
\hline \multicolumn{9}{|l|}{ Group B strains } \\
\hline CP-76 & $\mathrm{R} 1$ & A10 & $\mathrm{C} 9$ & H10 & M9 & N10 & $\mathrm{S} 10$ & $\mathrm{X}$ \\
\hline $\mathrm{UPM}-\mathrm{Ca} 7^{\mathrm{T}}$ & $\mathrm{R} 1$ & A10 & $\mathrm{C} 10$ & H10 & M9 & N10 & S10 & XI \\
\hline CP-92 & $\mathrm{R} 1$ & A10 & $\mathrm{C} 10$ & H11 & M10 & N10 & S11 & XII \\
\hline CP-77 & $\mathrm{R} 1$ & A10 & $\mathrm{C} 10$ & H11 & M10 & N10 & $\mathrm{S} 12$ & XIII \\
\hline 522 & R7 & A11 & C11 & $\mathrm{H} 12$ & M11 & N11 & S8 & XIV \\
\hline $3 \mathrm{HOa} 9$ & $\mathrm{R} 1$ & A12 & $\mathrm{C} 12$ & $\mathrm{H} 13$ & M12 & N12 & S13 & $X V$ \\
\hline \multicolumn{9}{|l|}{ Group C strains } \\
\hline CP-9 & R8 & A13 & $\mathrm{C} 13$ & $\mathrm{H} 2$ & M13 & N13 & S14 & XVI \\
\hline CP-91 & $\mathrm{R} 8$ & A13 & $\mathrm{C} 13$ & $\mathrm{H} 2$ & M13 & N13 & S14 & XVI \\
\hline USAB67 & $\mathrm{R} 1$ & A14 & $\mathrm{C} 14$ & H14 & M14 & N14 & S15 & XVII \\
\hline
\end{tabular}

${ }^{a}$ The numbers of electromorphs obtained with restriction enzymes RsaI, AluI, CfoI, HaeIII, MspI, NdeII, and Sau 96.1 were 8, 14, 14, 14, 14, 14, and 15, respectively; the numbers of bands larger than 90 bp per profile obtained with these enzymes were 4 to 5,6 to 9,6 to 10,8 to 12,8 to 10,4 to 6, and 6 to 8 , respectively.

group B strains. Genomic species 4 comprised two strains, IC-60 and $\mathrm{H}-45$, which exhibited $77 \%$ DNA relatedness with each other and less than $43 \%$ DNA relatedness with the remaining strains.

A total of eight strains belonging to groups $\mathrm{A}$ and $\mathrm{C}$ did not fall into any of the five genomic groups described above since they exhibited less than $63 \%$ DNA relatedness with all reference strains. These unclassified strains were not studied further by this method; however, they may represent one or more additional genomic species.

PCR amplification and RFLP of 16S IGS rDNA. A total of 24 strains were included in the RFLP study; 9 collection strains were used to represent the two major PCR RFLP-delineated clusters (24), and there were 15 new chickpea isolates. Gel electrophoresis of undigested PCR products revealed that all strains produced a single 2,500-bp band. The estimated length of the IGS between the $16 \mathrm{~S}$ and $23 \mathrm{~S}$ rDNAs found by subtracting the average length of the $16 \mathrm{~S}$ rDNAs of members of the Rhizobiaceae (34) (1,500 bp) from the 2,500 bp of 16S IGS rDNA was $1,000 \mathrm{bp}$.

The restriction patterns obtained for the strains are shown in Table 3 . Each restriction pattern was designated by a letter representing the enzyme, followed by a number representing the profile type. The seven enzymes tested generated 4 to 12 fragments per profile and a total of 178 different bands. Depending on the enzyme used, 8 to 15 electromorphs were obtained; RsaI was the least discriminatory enzyme. The 24 strains analyzed produced 17 different combinations of $16 \mathrm{~S}$ IGS rDNA electromorphs, which were designated I to XVII (Table 3). None of the enzymes was able to distinguish among strains Ca-7, IC-72M, and CP-14, between strains CP-9 and CP-91, or among strains CP-8, CP-18, CP-12, CP-24, and CP-
28. The similarity coefficients for and genetic distances between pairs of strains are shown in Table 4 . The values for similarity coefficients and genetic distances ranged from 59.2 to $100 \%$ and from 0 to 4.5 substitutions per site, respectively. An unweighted pair group with arithmetic average dendrogram was constructed from the distance matrix data (Fig. 1). A major division at 0.038 separated the strains into two clusters corresponding to the two major groups obtained previously (groups A and B) (24). Three strains formed an outgroup (group C) that diverged at 0.04 .

16S rRNA gene sequencing. The phylogenetic relationship between group A and B strains was estimated by determining the total 16S rRNA gene sequences of two strains, $R$. ciceri UPM-Ca $7^{\mathrm{T}}$ (group B) and a representative group A strain, strain UPM-Ca $36^{\mathrm{T}}$, which belongs to genomic species 2 . The $16 \mathrm{~S}$ rRNA sequences of the following organisms belonging to the Rhizobiaceae and other related bacteria were used for comparison: $R$. loti group B strain LMG4284; $R$. loti group A strain LMG6125 ; an isolate obtained from Acacia senegal, strain ORS1001; R. huakuii; P. myrsinacearum; S. meliloti LMG6133; S. fredii LMG6217; $R$. galegae LMG6214; Agrobacterium tumefaciens LMG196; $R$. tropici IFO15247; $R$. leguminosarum group A strain LMG9518; $R$. tropici group IIB strain LMG9517; Rhizobium sp. strain LMG9509; Agrobacterium rhizogenes LMG152; B. japonicum; and Azorhizobium caulinodans LMG6465.

The phylogenetic tree obtained and the bootstrap confidence limits for the tree are shown in Fig. 2. The similarity values and observed numbers of nucleotide differences for members of the branch comprising $R$. ciceri, $R$. loti, Rhizobium sp. strain UPM-Ca36 ${ }^{\mathrm{T}}$ (genomic species 2), strain ORS 1001, $R$. huakuii, and P. myrsinacearum are shown in Table 5. As 
TABLE 4. Levels of similarity and genetic distances for chickpea strains based on the results of a PCR RFLP analysis of 16S IGS rDNA

\begin{tabular}{|c|c|c|c|c|c|c|c|c|c|c|c|c|c|c|c|c|c|}
\hline \multirow[b]{2}{*}{ Strain } & \multicolumn{17}{|c|}{$\%$ Similarity or genetic distance $(\%)^{a}$} \\
\hline & $\begin{array}{l}\stackrel{\leftrightarrow}{N} \\
\stackrel{0}{U}\end{array}$ & 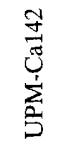 & $\begin{array}{l}\stackrel{4}{0} \\
\stackrel{0}{0}\end{array}$ & 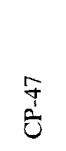 & U & 告 & $\vec{i}$ & $\frac{\infty}{\stackrel{\infty}{0}}$ & 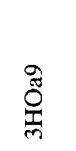 & 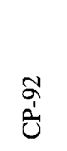 & $\begin{array}{l}F \\
\hat{U}\end{array}$ & $\frac{0}{0}$ & 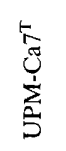 & $\widetilde{N}$ & $\frac{9}{8}$ & ì & 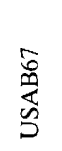 \\
\hline CP $-28^{b}$ & & 3.4 & 3.4 & 2.5 & 3.2 & 2.9 & 3.3 & 3.6 & 3.6 & 3.8 & 3.7 & 4.0 & 4.0 & 4.5 & 3.1 & 4.1 & $4.2^{=}$ \\
\hline UPM-Ca142 & 67.3 & & 2.3 & 3.2 & 2.9 & 3.0 & 3.5 & 3.2 & 3.8 & 3.7 & 3.6 & 3.7 & 3.7 & 3.9 & 2.7 & 4.4 & 3.9 \\
\hline CP-47 & 74.2 & 68.8 & 77.1 & & 2.8 & 2.7 & 2.1 & 2.6 & 3.4 & 3.3 & 3.2 & 3.6 & 3.6 & 3.2 & 2.4 & 4.0 & 3.8 \\
\hline IC-6 & 68.7 & 71.6 & 73.5 & 72.3 & & 3.4 & 3.0 & 3.0 & 3.3 & 4.1 & 4.0 & 3.8 & 3.8 & 3.4 & 2.8 & 3.9 & 3.4 \\
\hline $\mathrm{H}-45$ & 71.4 & 70.2 & 68.0 & 73.1 & 67.4 & & 3.2 & 3.5 & 3.8 & 3.7 & 3.6 & 3.7 & 3.7 & 4.1 & 3.0 & 3.0 & 3.6 \\
\hline $\mathrm{Ca}-7^{c}$ & 68.0 & 66.7 & 66.7 & 77.9 & 70.1 & 68.8 & & 3.1 & 4.2 & 3.9 & 3.8 & 4.1 & 4.1 & 3.8 & 3.1 & 4.3 & 4.3 \\
\hline CP-78 & 66.0 & 68.8 & 70.7 & 73.7 & 70.1 & 66.7 & 69.4 & & 3.7 & 3.9 & 3.8 & 3.9 & 3.9 & 3.8 & 2.9 & 4.5 & 4.3 \\
\hline $3 \mathrm{HOa} 9$ & 66.0 & 64.6 & 68.6 & 67.3 & 68.0 & 64.6 & 61.4 & 65.3 & & 3.3 & 3.2 & 3.1 & 3.1 & 4.3 & 3.1 & 3.9 & 3.5 \\
\hline CP-92 & 64.6 & 65.3 & 65.3 & 68.1 & 62.5 & 65.3 & 63.9 & 63.9 & 68.0 & & 0.3 & 1.3 & 1.1 & 2.6 & 3.3 & 4.1 & 4.3 \\
\hline $\mathrm{CP}-77$ & 65.3 & 66.0 & 66.0 & 68.8 & 63.2 & 66.0 & 64.6 & 64.6 & 68.7 & 96.8 & & 1.0 & 0.8 & 2.5 & 3.0 & 4.1 & 4.1 \\
\hline UPM-Ca $7^{\mathrm{T}}$ & 62.6 & 65.3 & 65.3 & 66.0 & 64.6 & 65.3 & 61.9 & 63.9 & 70.0 & 87.5 & 90.5 & 97.9 & & 2.9 & 3.0 & 4.1 & 4.3 \\
\hline 522 & 59.4 & 63.9 & 62.0 & 68.8 & 67.3 & 61.9 & 64.6 & 64.6 & 60.8 & 73.5 & 74.2 & 71.4 & 71.4 & & 3.8 & 4.3 & 4.1 \\
\hline CP-19 & 70.0 & 72.9 & 70.7 & 75.8 & 72.2 & 70.8 & 69.4 & 71.4 & 69.3 & 68.0 & 70.8 & 70.1 & 70.1 & 64.6 & & 3.7 & 4.0 \\
\hline CP-9 $9^{d}$ & 62.0 & 60.4 & 60.6 & 63.2 & 63.9 & 70.8 & 61.2 & 59.2 & 63.4 & 61.9 & 62.5 & 59.8 & 61.9 & 60.6 & 65.3 & & 3.2 \\
\hline USAB67 & 61.4 & 63.9 & 60.0 & 64.6 & 67.3 & 66.0 & 60.6 & 60.6 & 66.7 & 61.2 & 61.9 & 61.2 & 61.2 & 62.0 & 62.6 & 68.7 & \\
\hline
\end{tabular}

${ }^{a}$ Levels of similarity and genetic distances are shown on the lower left and on the upper right, respectively. Genetic distance values were derived from pairwise levels of similarity between restriction fragments corrected by using the method of $\mathrm{Nei}$ and $\mathrm{Li}(22)$.

${ }^{b}$ Strains CP-12, CP-24, CP-18, and CP-8 had the same levels of similarity and genetic distances as CP-28.

${ }^{c}$ Strains IC-72M and CP-14 had the same levels of similarity and genetic distances as Ca-7.

${ }^{d}$ Strain CP-91 had the same levels of similarity and genetic distances as CP-9.

previously described on the basis of partial 16S rRNA sequences (25), the $R$. ciceri type strain clustered on the $R$. lot $i$ branch. Total sequence comparisons performed with $R$. ciceri gave similarity coefficients of 0.998 (three nucleotide differences) and 0.999 (two nucleotide differences) with $R$. loti groups A and B, respectively. This group formed a tight cluster that was corroborated by a bootstrap confidence value of 100 . Chickpea strain UPM-Ca36 ${ }^{\mathrm{T}}$ grouped with $R$. huakuii and strain ORS1001 cluster $U$ and exhibited similarity coefficients of 0.992 (11 nucleotide differences) and 0.987 (17 nucleotide differences) with these two taxa. Thus, chickpea strains $R$. ciceri UPM-Ca $7^{\mathrm{T}}$ and UPM-Ca $36^{\mathrm{T}}$ fell into different clusters. The similarity coefficient for these two strains was 0.986 , corresponding to 19 base differences. All of the strains mentioned above formed part of a larger group (bootstrap confidence value, 98) which was separated from other Rhizobium species (R. leguminosarum, $R$. galegae, $R$. tropici) by strains belonging to other genera of the Rhizobiaceae, such as the genera Sinorhizobium, Agrobacterium, and Phyllobacterium (Fig. 2), as well as by organisms belonging to other families not represented in this study, such as Rochalimea, Mycoplana, and Brucella strains (7).

\section{DISCUSSION}

In a study of the diversity of rhizobial isolates that nodulate chickpeas (C. arietinum $\mathrm{L}$.), we recently determined that there are two phylogenetic lineages (groups $\mathrm{A}$ and B) by using a polyphasic approach $(24,25)$. We showed that these two groups of strains belong to the same genus, the genus Rhizobium, but are distinct from all previously described species. Preliminary DNA homology results obtained with four strains showed that the two group $B$ strains did not belong to the same genomic species as the group A strains. The group B strains clustered close to $R$. loti, but could be clearly separated from this species on the basis of their partial 16S rRNA sequences, the results of a PCR RFLP analysis of the 16S IGS rDNA, their phenotypic characteristics, and DNA homology values; thus, these strains were assigned to a new species, $R$. ciceri. The group A strains were found to be more heterogeneous and remained unnamed. In this study we examined 30 chickpea strains isolated from very diverse geographic areas representing the different regions where chickpeas are grown. The results of a PCR RFLP analysis of the 16S IGS rDNA, which previously correlated well with the results obtained with other approaches $(24,25)$, were used to group the new strains. Because of the heterogeneity observed previously, and the fact that some strains could not be classified as $R$. ciceri strains, we questioned how many new species the chickpea strains belong to, performed DNA-DNA hybridization experiments, and determined $\Delta T_{m}$ values. Moreover, despite the high levels of divergence between members of groups $\mathrm{A}$ and $\mathrm{B}$ that we found, these organisms had identical partial 16S rRNA sequences (25). Thus, in order to determine the phylogenetic position of these organisms, their total 16S rRNA sequences were determined.

The clusters obtained when we used the PCR RFLP method with 30 strains confirmed that the chickpea isolates should be divided into two major phylogenetic groups, groups A and B $(24,25)$. These groups diverged at a genetic distance of approximately 0.038 substitution per site. The DNA relatedness values were consistent with these results since the group $\mathrm{A}$ strains exhibited higher average DNA relatedness values with each other than with group B strains. The level of genetic diversity observed within the groups varied, depending on the group considered. The group B strains appeared to be very homogeneous, but much greater heterogeneity was observed among the group A strains when DNA-DNA relatedness and PCR RFLP methods were used. Most of the group B strains belonged to the same genomic species, $R$. ciceri; the only exception was group B strain $3 \mathrm{HOa} 9$, which exhibited low levels of DNA relatedness with $R$. ciceri strains and was excluded 


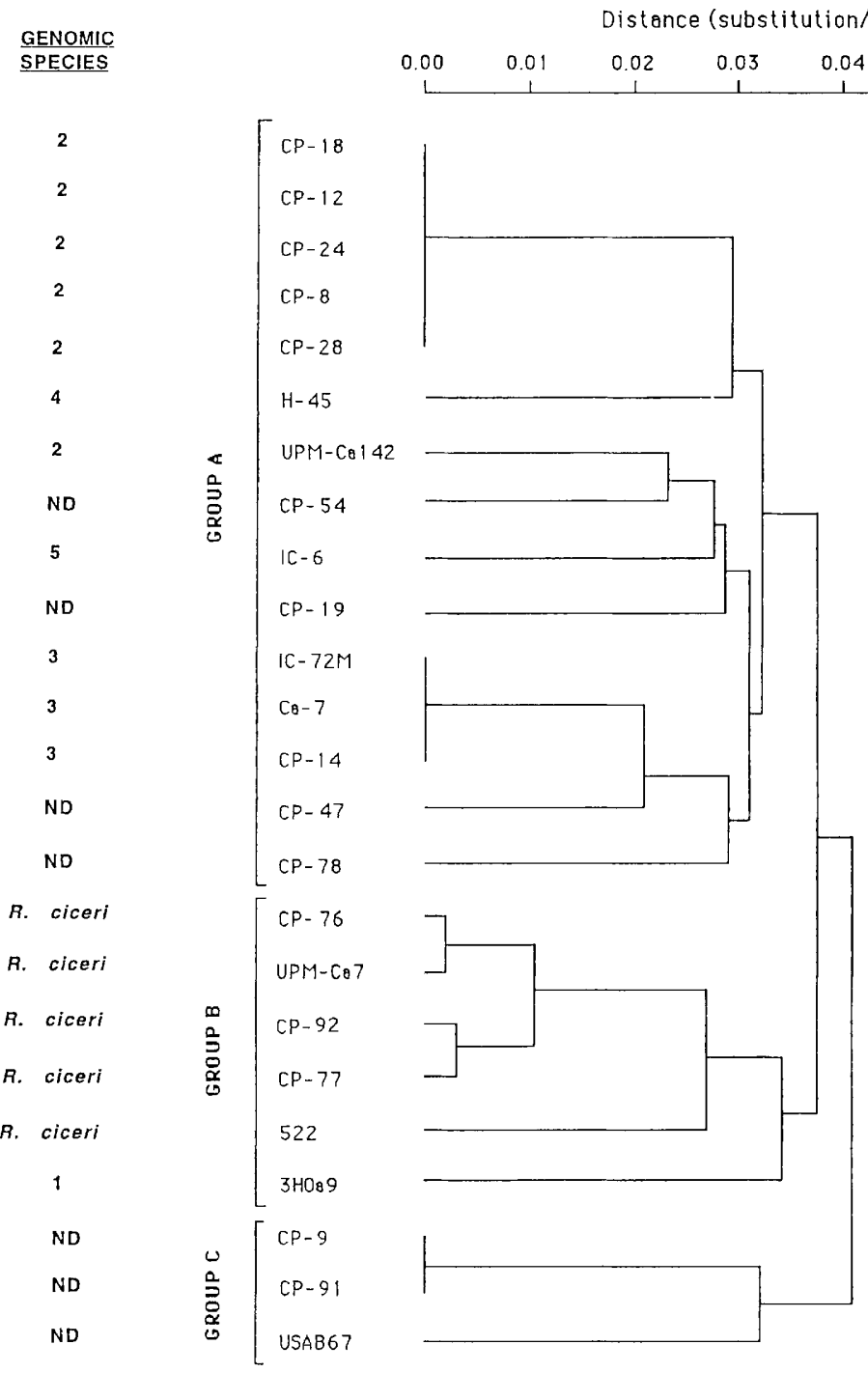

FIG. 1. Genetic distances between chickpea rhizobia based on the results of an RFLP analysis of the amplified 16S IGS rDNA region. ND, not determined.

from this species when the PCR RFLP method was used. This strain may represent a separate group $B$ genomic species. The group A strains were grouped into three genomic species, and five strains remained unclassified. This heterogeneity is reflected by the divergent branches on the PCR RFLP dendrogram (Fig. 1). Our overall results revealed that there was a good correlation between DNA homology data, which led to the delineation of genomic species, and polymorphism of the 16S IGS rDNAs. For example, genomic species 3 strains IC72M, Ca-7, and CP-14 formed a tight 16S IGS rDNA cluster among the group A strains. Similarly, all of the genomic species 2 strains except strain UPM-Ca142 grouped tightly (Fig. 1). We concluded that strains CP-9 and CP-91, which produced identical PCR RFLP profiles with all seven restriction enzymes tested, probably belong to the same genomic species. Thus, the PCR RFLP method used in this study not only is a good method for fingerprinting strains but also can be used to screen large numbers of strains and classify them into their probable genomic species.

Some of the genomic species which we identified have a wide geographic distribution, and others appear to be confined to one geographic area. $R$. ciceri and genomic species 2 are found in the Mediterranean area, North Africa, North America, the Indian subcontinent, and Russia, while genomic species 3 and 4 were obtained from the Indian subcontinent. However, genomic species 3 and 4 included only a few strains, and thus it is not possible to confirm that they are limited to the Indian subcontinent.

Because of the great heterogeneity of the strains that nodulate chickpeas (there are at least five genomic species among the 30 isolates which we studied, and group A and B strains exhibit high levels of divergence), we reconsidered our previous conclusion that group $\mathrm{A}$ and $\mathrm{B}$ strains comprise a unique phylum based on identical partial 16S rRNA gene sequences. The partial sequence that includes the first 250 nucleotides from the $5^{\prime}$ part of the $16 \mathrm{~S}$ rRNA gene is commonly considered to represent the most heterogeneous region in the $16 \mathrm{~S}$ rRNA gene, but in certain cases this assumption leads to erroneous phylogenetic positions. For example, the partial sequences of $R$. galegae strains placed this species on the $R$. loti$R$. huakuii branch (25), far from its position on the Agrobacterium vitis-Agrobacterium tumefaciens-Agrobacterium rubi branch 


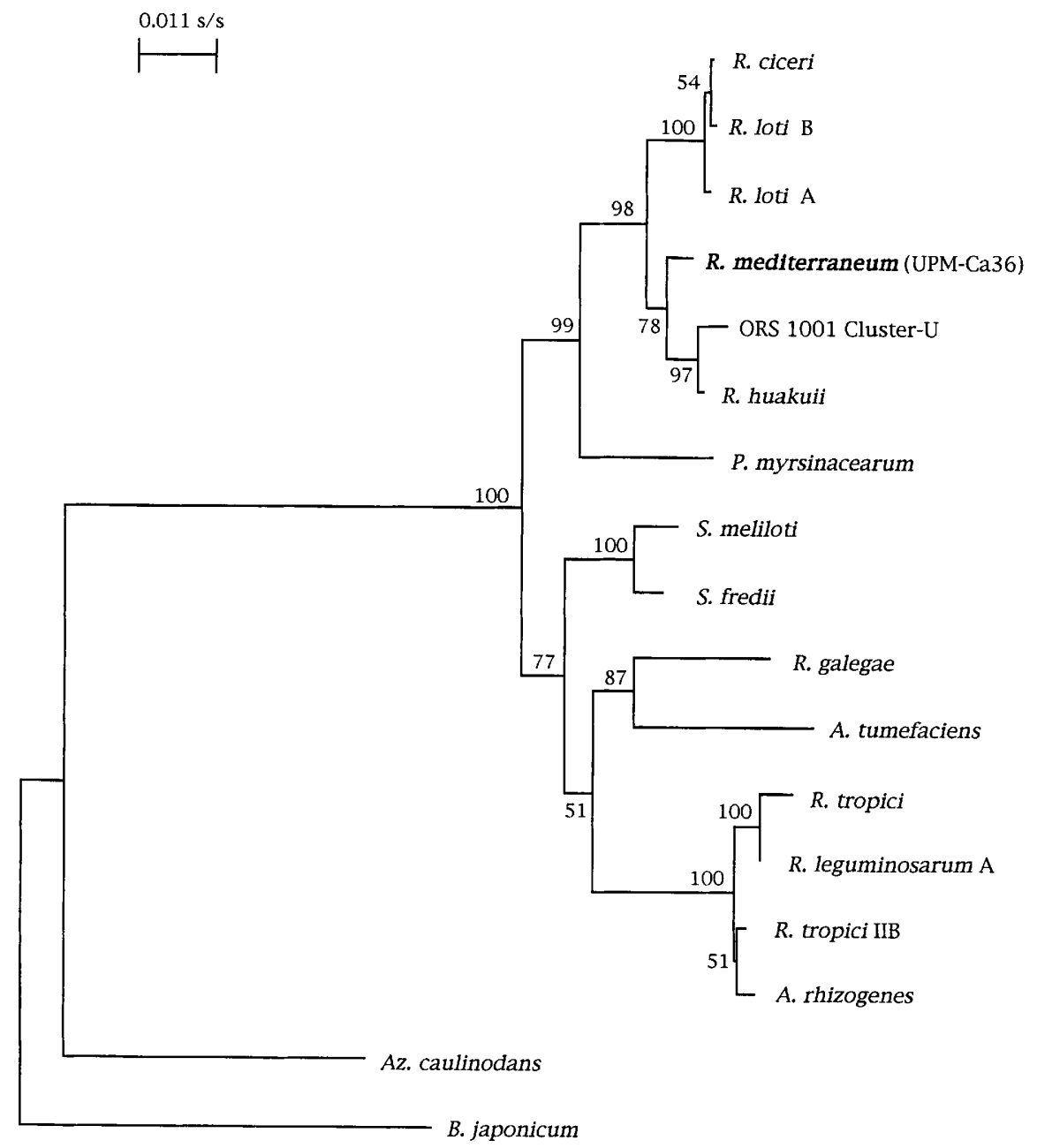

FIG. 2. Phylogenetic tree for the alpha subclass of the Proteobacteria, obtained by using complete $16 \mathrm{~S}$ rRNA gene sequences and the neighbor-joining method. Significant bootstrap probability values are indicated at the nodes. Abbreviations: s/s, substitution per site, $R$., Rhizobium; $P$., Phyllobacterium; $S$., Sinorhizobium; $A$., Agrobacterium; B., Bradyrhizobium; Az., Azorhizobium.

determined by a total $16 \mathrm{~S}$ rRNA sequence analysis (7). Our results showed that the position of $R$. ciceri on the $16 \mathrm{~S}$ rRNA phylogenetic tree did not change and that this species clustered tightly with $R$. loti. Thus, in this case, the partial sequences accurately predicted the phylogenetic position of the strains, since of the three nucleotide differences in the total $16 \mathrm{~S}$ rRNAs of $R$. ciceri and $R$. loti group A, two were observed in the partial sequences of the first one-fifth of the gene. In contrast, we were not able to predict levels of phylogenetic divergence for $R$. huakuii and $R$. ciceri on the basis of partial sequences, since 1 mismatch was observed in the first $250 \mathrm{nu}$ cleotides and there were 24 mismatches over the whole length of the gene. Strain UPM-Ca36 ${ }^{\mathrm{T}}$, which represents genomic species 2 , belongs to the $R$. huakuii branch and was well separated from the other reference strains, particularly $R$. ciceri UPM-Ca $7^{\mathrm{T}}$ (19 nucleotide differences), even though the partial sequences of the two strains were identical. Thus, on the basis of $16 \mathrm{~S}$ rRNA gene sequence data, $R$. ciceri and genomic species 2 were phylogenetically distinct, constituting two distinct lineages of the $R$. loti-R. huakuii subgroup. Consistent with these results, genomic species 2 exhibited low levels of DNA homology with $R$. ciceri and other members of the Rhizobiaceae $(<17 \%)(25)$.
On the basis of the cumulative genotypic results obtained in this study (DNA relatedness values, the results of the analysis of the polymorphism of the 16S IGS rDNA, and total $16 \mathrm{~S}$ rRNA sequence data), as well as the previous phenotypic multilocus enzyme electrophoresis results and cultural and physiological characteristics $(24,25)$ which strongly separated groups $\mathrm{A}$ and $\mathrm{B}$, we suggest that genomic species 2 is a species that is distinct from $R$. ciceri. Therefore, we propose that genomic species 2 strains isolated from $C$. arietinum $\mathrm{L}$. should be assigned to a new species, Rhizobium mediterraneum (med.i.ter. ra'ne.um. L. adj. mediterraneum, of the Mediterranean, one of the primary centers of origin from which chickpea plants were disseminated throughout the world).

Genomic species 3 and 4 belong to group A together with $R$. mediterraneum, and even though they can be clearly distinguished from this species on the basis of DNA homology data and the polymorphism of the rDNA, they have not yet been differentiated by phenotypic features or $16 \mathrm{~S}$ rRNA sequence data. Moreover, few strains belong to these two genomic species, and thus we propose that more data will be required before they are named. Similarly, the status of the three strains belonging to group $\mathrm{C}$ which differ from both group $\mathrm{A}$ and $\mathrm{B}$ strains needs to be clarified. 
TABLE 5. Similarity coefficients and observed numbers of nucleotide differences based on whole $16 \mathrm{~S}$ rRNA gene sequences

\begin{tabular}{|c|c|c|c|c|c|c|c|}
\hline \multirow[b]{2}{*}{ Taxon } & \multicolumn{7}{|c|}{$\begin{array}{c}\text { Similarity coefficient or observed } \\
\text { no. of differences }{ }^{a t}\end{array}$} \\
\hline & 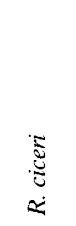 & 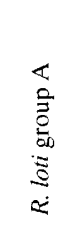 & 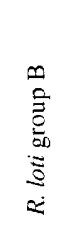 & 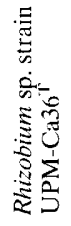 & 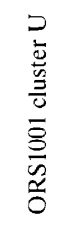 & 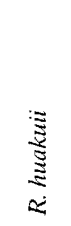 & 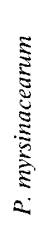 \\
\hline R. ciceri & & 3 & 2 & 19 & 28 & 24 & 46 \\
\hline R. loti group A & 0.998 & & 3 & 21 & 27 & 23 & 45 \\
\hline R. loti group B & 0.999 & 0.998 & & 20 & 30 & 24 & 46 \\
\hline $\begin{array}{l}\text { Rhizobium sp. strain } \\
\text { UPM-Ca } 36^{\mathrm{T}}\end{array}$ & 0.986 & 0.985 & 0.985 & & 17 & 11 & 50 \\
\hline ORS1001 cluster U & 0.979 & 0.980 & 0.978 & 0.987 & & 6 & 47 \\
\hline R. huakuii & 0.982 & 0.983 & 0.982 & 0.992 & 0.996 & & 48 \\
\hline P. myrsinacearum & 0.966 & 0.967 & 0.966 & 0.963 & 0.965 & 0.964 & \\
\hline
\end{tabular}

a The similarity coefficients and the observed numbers of nucleotide differences are shown on the lower left and on the upper right, respectively.

Description of Rhizobium mediterraneum sp. nov. Gram-negative, aerobic, non-spore-forming rods. Colonies on yeast extract-mannitol agar are convex, opaque, and $2 \mathrm{~mm}$ in diameter within 4 to 5 days when cultures are incubated at $28^{\circ} \mathrm{C}$. $R$. mediterraneum can be differentiated from other species belonging to the Rhizobiaceae by the following characteristics: total 16S rRNA sequence, DNA-DNA relatedness data, multilocus enzyme electrophoresis data (24), and polymorphism of the $16 \mathrm{~S}$ IGS rDNA. Two representative strains of the species, UPM-Ca36 ${ }^{\mathrm{T}}$ and UPM-Ca142, which have been studied previously by performing different phenotypic tests and an isozyme polymorphism analysis (24), clearly group together and are separated from the other chickpea isolates. These two strains have the following characteristics in common with the other group A strains (24): the maximum temperature for growth is $40^{\circ} \mathrm{C}$, they are able to grow on minimal media, they tolerate $2 \%(\mathrm{wt} / \mathrm{vol}) \mathrm{NaCl}$, and they grow at $\mathrm{pH} 9.5$. The characteristics that differentiate UPM-Ca36 ${ }^{\mathrm{T}}$ and UPM-Ca142 from $R$. ciceri are their inability to grow at $\mathrm{pH} 10$ and 5, their susceptibility to carbenicillin, and their resistance to chloramphenicol, nalidixic acid, and trimethoprim-sulfamethoxazole. Strain UPM-Ca36, which was isolated from nodulated chickpeas grown in Spain, is the type strain. This strain has the characteristics described above for $R$. mediterraneum $\mathrm{sp}$. nov. Strain UPM-Ca36 ${ }^{\mathrm{T}}$ has been deposited in the American Type Culture Collection.

\section{ACKNOWLEDGMENTS}

We are grateful to Jacqueline Haurat for excellent technical assistance in DNA sequencing. We also thank D. Beck and M. Saxena for their invaluable support and for providing the strains used in this study.

S. Nour received a joint research grant from the Bureau of International Relations of the Institut National de la Recherche Agronomique, France, and the International Center for Agricultural Research in Dry Areas, Aleppo, Syria.

\section{REFERENCES}

1. Bosco, M., S. Jamann, C. Chapelon, P. Simonet, and P. Normand. 1994. Frankia microsymbiont in Dryas drummondii nodules is closely related to the microsymbiont of Coriaria and genetically distinct from other characterized Frankia strains, p. 173-183. In N. A. Hegazi, M. Fayez, and M. Monib (ed.), Nitrogen fixation with non-legumes. The American University in Cairo Press, Cairo.

2. Brenner, D. J., A. C. McWorter, J. K. L. Knuston, and A. G. Steigerwalt. 1982. Escherichia vulneris: a new species of Enterobacteriaceae associated with human wounds. J. Clin. Microbiol. 15:1133-1140.

3. Cadahia, E., A. Leyvar, and T. Ruiz-Argueso. 1986. Indigenous plasmids and cultural characteristics of rhizobia nodulating chickpeas (Cicer arietinum L.). Arch. Microbiol. 146:239-244.

4. Chen, W. X., G. S. Li, Y. L. Qi, E. T. Wang, H. L. Yuan, and J. L. Li. 1991. Rhizobium huakuii sp. nov. isolated from the root nodules of Astragalus sinicus. Int. J. Syst. Bacteriol. 41:275-280.

5. Crosa, J. M., D. J. Brenner, and S. Falkow. 1973. Use of a single-strandspecific nuclease for analysis of bacterial and plasmid deoxyribonucleic acid homo- and heteroduplexes. J. Bacteriol. 115:904-911.

6. Dadarwal, K. R. 1980 . Host bacterium factors involved in legume symbiosis. Indian J. Microbiol. 20:245-252.

7. De Lajudie, P., A. Willems, B. Pot, D. Dewettinck, G. Maestrojuan, M. Neyra, M. D. Collins, B. Dreyfus, K. Kersters, and M. Gillis. 1994. Polyphasic taxonomy of rhizobia: emendation of the genus Sinorhizobium and description of Sinorhizobium meliloti comb. nov, Sinorhizobium sahel sp. nov., and Sinorhizobium teranga sp. nov. Int. J. Syst. Bacteriol. 44:715733.

8. Felsenstein, J. 1985. Confidence limits on phylogenies: an approach using the bootstrap. Evolution 39:783-791.

9. Fernandez, M. P., H. Meugnier, P. A. D. Grimont, and R. Bardin. 1989 Deoxyribonucleic acid relatedness among members of the genus Frankia. Int. J. Syst. Bacteriol. 39:424-429.

10. Gaur, Y. D., and A. N. Sen. 1979. Cross inoculation group specificity in Cicer rhizobium symbiosis. New Phytol. 83:745-754

11. Grimont, P. A. D. 1988. Use of DNA reassociation in bacterial classification. Can. J. Bacteriol. 34:541-546.

12. Grimont, P. A. D., M. Y. Popoff, F. Grimont, C. Coynault, and M. Lemelin. 1980. Reproducibility and correlation study of three deoxyribonucleic acid hybridization procedures. Curr. Microbiol. 4:325-330.

13. Higgins, D. G., and P. M. Sharp. 1988. Clustal: a package for performing multiple alignment on a microcomputer. Gene 73:237-244.

14. Jarvis, B. D. W., C. E. Pankhurst, and J. J. Patel. 1982. Rhizobium loti, a new species of legume-root nodule bacteria. Int. J. Syst. Bacteriol. 32:378380

15. Jordan, D. C. 1984. Family III. Rhizobiaceae, p. 234-242. In N. R. Krieg and J. G. Holt (ed.), Bergey's manual of systematic bacteriology, vol. 1. The Williams \& Wilkins Co., Baltimore.

16. Kimura, M. 1980. A simple method for estimating evolutionary rates of base substitutions through comparative studies of nucleotide sequences. J. Mol Evol. 16:111-120.

17. Kingsley, M. T., and B. B. Bohlool 1983. Characterization of Rhizobium sp. (Cicer arietinum $\mathrm{L}$.) by immunofluorescence, immunodiffusion and intrinsic antibiotic resistance. Can. J. Microbiol. 29:518-526.

18. Lindstrom, K. 1989. Rhizobium galegae, a new species of legume root nodule bacteria. Int. J. Syst. Bacteriol. 39:365-367.

19. Maniatis, T., E. F. Fritsch, and J. Sambrook. 1982. Molecular cloning: a laboratory manual. Cold Spring Harbor Laboratory, Cold Spring Harbor, N.Y.

20. Martinez-Romero, E., L. Segovia, F. M. Mercante, A. A. Franco, P. Graham, and M. A. Pardo. 1991. Rhizobium tropici, a novel species nodulating Phaseolus vulgaris L. beans and Leucaena sp. trees. Int. J. Syst. Bacteriol. 41:417426.

21. Mullis, K. B., and F. A. Faloona. 1987. Specific synthesis of DNA in vitro via a polymerase catalysed chain reaction. Methods Enzymol. 155:335350 .

22. Nei, M., and W. H. Li. 1979. Mathematical model for studying genetic variation in terms of restriction endonucleases. Proc. Natl. Acad. Sci. USA 76:5269-5273.

23. Normand, P., B. Cournoyer, P. Simonet, and S. Nazaret. 1992. Analysis of a ribosomal RNA operon in the actinomycete Frankia. Gene 111:119 124

24. Nour, S. M., J. C. Cleyet-Marel, D. Beck, A. Effosse, and M. P. Fernandez 1994. Genotypic and phenotypic diversity of Rhizobium isolated from chickpea (Cicer arietinum L.). Can. J. Microbiol. 40:345-354.

25. Nour, S. M., M. P. Fernandez, P. Normand, and J. C. Cleyet-Marel. 1994 Rhizobium ciceri sp. nov., consisting of strains that nodulate chickpeas (Cicer arietinum L.). Int. J. Syst. Bacteriol. 44:511-522.

26. Rigby, P. W. J., M. Dieckmann, C. Rhodes, and P. Berg. 1977. Labeling deoxyribonucleic acid to high specific activity in vitro by nick translation with DNA polymerase I. Int. J. Syst. Bacteriol. 27:237-251.

27. Saitou, N., and M. Nei. 1987. A neighbour-joining method: a new method for reconstructing phylogenetic trees. Mol. Biol. Evol. 44:406-425.

28. Sanger, F., S. Nicklen, and A. R. Coulson. 1977. DNA sequencing with chain-terminating inhibitors. Proc. Natl. Acad. Sci. USA 74:5463-5467.

29. Scholla, M. H., and G. H. Elkan. 1984. Rhizobium fredii sp. nov., a fast- 
growing species that effectively nodulates soybeans. Int. J. Syst. Bacteriol. 34:484-486.

30. Segovia, L., J. P. W. Young, and E. Martinez-Romero. 1993. Reclassification of American Rhizobium leguminosarum biovar phaseoli type I strains as Rhizobium etli sp. nov. Int. J. Syst. Bacteriol. 43:374-377.

31. Sneath, P. H. A., and R. R. Sokal. 1973. Numerical taxonomy. W. H. Freeman and Sons, San Francisco.

32. Vincent, J. M. 1970. A manual for the practical study of root-nodule bacteria.
I. B. P. Handbook no. 15, p. 3-4. Blackwell Scientific Publications, Oxford. 33. Wayne, L. G., D. J. Brenner, R. R. Colwell, P. A. D. Grimont, O. Kandler, M. I. Krichevsky, L. H. Moore, W. E. C. Moore, R. G. E. Murray, E. Stackebrandt, M. P. Starr, and H. G. Truper. 1987. Report of the Ad Hoc Committee on Reconciliation of Approaches to Bacterial Systematics. Int. J. Syst. Bacteriol. 37:463-464.

34. Willems, A., and M. D. Collins. 1993. Phylogenetic analysis of rhizobia and agrobacteria based on 16S rRNA gene sequences. Int. J. Syst. Bacteriol. 43:305-313. 